\title{
Reevaluation of the Growth-Permissive Substrate Properties of Goldfish Optic Nerve Myelin and Myelin Proteins
}

\author{
Marion Wanner, ${ }^{1}$ Dirk M. Lang, ${ }^{1}$ Christine E. Bandtlow, ${ }^{2}$ Martin E. Schwab, ${ }^{2}$ Martin Bastmeyer, ${ }^{1}$ and Claudia
} A. O. Stuermer ${ }^{1}$

'Faculty of Biology, University of Konstanz, D-78434 Konstanz, Germany and ${ }^{2}$ Institute for Brain Research, University of Zurich, $\mathrm{CH}-8029$ Zurich, Switzerland

To determine whether optic nerve myelin of goldfish carries mammalian-like neurite growth inhibitory proteins which can be neutralized by the antibody IN-1, myelin fractions of fish optic nerves were used as substrates for fish retinal ganglion cell axons and rat dorsal root ganglia (DRG). Axonal growth was monitored and compared with that of IN-1 treated preparations. Growth of fish retinal axons and rat DRG neurites was substantial on goldfish optic nerve myelin and no improvement was observed with $\mathrm{IN}-1$. In contrast, rat CNS myelin allowed only poor growth, and number of axons and length of DRG neurites increased significantly with IN-1. In addition, proteins of fish optic nerve myelin and bovine CNS myelin were extracted, reconstituted in liposomes and applied to growth cones. When goldfish myelin proteins in liposomes were seeded onto growth cones, $77 \%$ of fish and $89 \%$ of rat DRG growth cones continued to elongate, and the proportion of elongating fish growth cones $(80 \%)$ did not significantly change when liposomes were pretreated with $1 \mathrm{~N}-1$. But $73 \%$ of fish and $\mathbf{9 3 \%}$ of rat growth cones collapsed with liposomes containing proteins from bovine CNS myelin. Upon IN-1 treatment, only $24 \%$ of fish growth cones collapsed.

Thus, axon growth in vitro indicates that goldfish optic nerves, which permit successful axon regeneration in vivo, lack mammalian-like neurite growth inhibitors which are neutralized by IN-1.

[Key words: substrate properties, goldfish optic nerve, growth permissivity, extracted proteins, antibody $I N-1, I i-$ posomes, rat DRGs]

Whether neurons are capable of regenerating their axons after injury of CNS fiber tracts appears to depend on the properties of the glial cell environment as well as on neuron-intrinsic properties (Fawcett, 1992; Stuermer et al., 1992). In the fish visual system both the glial cell environment and the response of axotomized neurons are obviously suitable for regrowth of retinal axons upon optic nerve transection; axons regenerate to full recovery of function (Gaze, 1973). Fish retinal ganglion cells

\footnotetext{
Received May 8, 1995; revised July 11, 1995; accepted July 14, 1995

We thank Mary A. Cahill for correcting an early version of the English text and Barbara Niederoest for technical assistance. D.M.L. is a doctoral fellow of the Boehringer Ingelheim Fonds. This work was supported by grants of the Deutsche Forschungsgemeinschaft (DFG), SFB 156 TP C6 to C.A.O.S., and the Gemeinniutzige Hertie-Stiftung.

Correspondence should be addressed to Claudia $A$. O. Stuermer at the above address.

Copyright 1995 Society for Neuroscience $0270-6474 / 95 / 157500-09 \$(05.00 / 0)$
}

upregulate their mRNA production and reexpress several growth associated proteins concurrent with axonal regrowth (Grafstein and McQuarrie, 1978; Perry et al., 1987; Stuermer et al., 1992). This indicates that these neurons reactivate the cellular maschinerie required for axonal extension. The majority of neurons in the mammalian CNS lack this ability (Aguayo et al., 1991). They form abortive sprouts, and fail to grow long axons in the CNS environment. Besides "reactive" astrocytes (Bähr and Bonhoeffer, 1994), oligodendrocytes contribute to the nonpermissive substrate properties of the mammalian CNS (Schwab et al., 1993).

Oligodendrocytes and CNS myelin of mammals exhibit neurite growth inhibitors of 35 and $250 \mathrm{kDa}$ (Caroni and Schwab, 1988a), which impair axonal regeneration (Schnell et al., 1994) and elicit growth cone collapse in vitro (Bandtlow et al., 1990, 1993). In contrast to mammals, myelin of goldfish (Bastmeyer et al., 1991) and Xenopus (Lang et al., 1995) optic nerves are growth permissive substrates for elongating axons in vitro. This correlates with the success of axonal regeneration in these systems following optic nerve transection in vivo (Gaze, 1970). Moreover, growth cones of goldfish regenerating retinal axons were observed in direct contact with myelin fragments in the severed optic nerve (Strobel and Stuermer, 1994) supporting the notion that fish CNS myelin does not exert a repellent influence on these axons. This is consistent with earlier studies showing that chick retinal (Vanselow et al., 1990) and rat DRG axons (Carbonetto et al., 1987) freely cross fish CNS myelin or myelinated territories on tissue sections, respectively. Fish retinal axons, however, as most neurons studied to date, are sensitive to mammalian inhibitory proteins (Bastmeyer et al., 1991). The growth-permissive properties of fish and amphibian optic nerves (Lang et al., 1995) suggested that oligodendrocytes and myelin, at least of these CNS domains, lack neurite growth inhibitors or exhibit only trace amounts which do not negatively affect axonal regeneration.

This notion has recently been questioned in the case of fish in a series of reports (Sivron and Schwartz, 1994a,b; Sivron et al., 1994). These authors propose that goldfish optic nerve myelin does possess neurite growth inhibitors which are claimed to be neutralized by the antibody IN-1 directed against the mammalian inhibitory proteins (Caroni and Schwab, 1988b). To account for the regenerative regrowth of fish retinal axons in vivo, these authors suggest that resident oligodendrocytes are killed and that myelin debris is quickly removed from the nerve after lesion (Sivron et al., 1991) and that increased in addition the content of growth supportive molecules for axonal regeneration (Hopkins et al., 1985; Battisti et al., 1992). 
On this background we reinvestigated the substrate properties of CNS myelin of the goldfish optic nerve, in three sets of experiments.

(1) We examined whether the growth of goldfish retinal axons on goldfish optic nerve derived myelin can be improved by IN-1.

(2) We investigated if goldfish optic nerve myelin would allow neurite growth of rat DRGs, because rat DRGs are known to be affected by neurite growth inhibitors if present.

(3) Myelin proteins were isolated from goldfish optic nerve according to an established procedure resulting in the enrichment of the inhibitors if present. These proteins were reconstituted in liposomes (Bandtlow et al., 1993) and applied to elongating growth cones in vitro, in the absence and presence of the antibody IN-1.

Results underscore our previous findings that goldfish optic nerve myelin is growth permissive (Bastmeyer et al., 1991; Lang et al., 1995), and IN-1 failed to improve its substrate properties.

\section{Materials and Methods}

Immunocytochemistry. Adult goldfish (Carassius auratus, 1 year old, $5-7 \mathrm{~cm}$ body length) from our own breeding colony were anesthetized in $0.03 \%$ Tricaine methanesulfonate (MS-222, Sigma) and decapitated. Brain, spinal cord, and optic nerves were removed and embedded together in Tissue-Tek (O.C.T. Compound, Miles Inc.). Brains with cranial nerves and spinal cords with spinal nerves were carefully dissected to include PNS structures in IN-I immunostaining experiments. All tissues were frozen in liquid nitrogen and stored at $-70^{\circ} \mathrm{C}$ for further processing. Cryostat sections $(12 \mu \mathrm{m})$ were cut, mounted on slides coated with VECTABOND reagent (following the instructions by Vector Laboratories) and dried for $30 \mathrm{~min}$. Sections were fixed in Clark's solution (95\% ethanol, $5 \%$ acetic acid) for $25 \mathrm{~min}$ at $4^{\circ} \mathrm{C}$, rehydrated $(90 \%$ ethanol, $70 \%$ ethanol, $10 \mathrm{~min}$ each), and rinsed three times in phosphate buffered saline (PBS). Sections were labeled with monoclonal antibody (Mab) IN-1 against neurite growth inhibitors (Caroni and Schwab, $1988 \mathrm{~b}$ ) and Mab 6D2 (1:2 in PBS) against fish myelin proteins (Jeserich and Waehneldt, 1986; kindly provided by $G$. Jeserich). Incubation with both antibodies was $1.5 \mathrm{hr}$ at $37^{\circ} \mathrm{C}$, after which sections were rinsed in PBS and incubated in secondary antibodies for $90 \mathrm{~min}$ at $37^{\circ} \mathrm{C}$. Cy3 conjugated donkey anti-mouse IgM $\mu$ chain specific antibody (1:1000 in PBS) was used for Mab IN-1 and Cy3-conjugated donkey anti-mouse IgG $(\mathrm{H}+\mathrm{L})$ antibodies (1:1000 in PBS, both from Jackson ImmunoResearch) for Mab 6D2. Sections were washed again in PBS, embedded in Mowiol (Hoechst) and viewed in a Zeiss Axiophot using the appropriate filter sets. Control sections were incubated with secondary antibodies only, which gave no staining.

Myelin preparation. Myelin of goldfish optic nerves, and of rat spinal cord was prepared as previously described (Caroni and Schwab, 1988a; Bastmeyer et al., 1991). Briefly, goldfish optic nerves and adult rat spinal cords were rapidly dissected free in ice-cold PBS and transferred to homogenization buffer $(10 \mathrm{~mm}$ Tris- $\mathrm{HCl}, 2 \mathrm{~mm} \mathrm{CaCl}, 1 \mathrm{~mm}$ EDTA, $25 \mu \mathrm{g} / \mathrm{ml}$ aprotinine, $25 \mu \mathrm{g} / \mathrm{ml}$ leupeptine, $5 \mu \mathrm{g} / \mathrm{ml}$ pepstatin, $50 \mathrm{mM}$ 2,3-dehydro-2-deoxy- $N$-acctylncuraminic acid, $5 \mathrm{~mm}$ iodoacetamide, and $1 \mathrm{~mm}$ spermidine; all protease inhibitors from Sigma). After homogenization, fractions enriched in myelin were obtained through centrifugation at $23,000 \mathrm{rpm}$ for $12 \mathrm{~min}$ at $4^{\circ} \mathrm{C}$ in a sucrose step gradient (20\% and $50 \%$ sucrose for goldfish optic nerve myelin; $15 \%, 25 \%$, and $50 \%$ sucrose for rat spinal cord myelin, all in homogenization buffer; modified after Colman et al., 1982). Myelin-enriched fractions were washed three times at $4^{\circ} \mathrm{C}$ in PBS containing protease inhibitors and used immediately for outgrowth assays. The concentration of myelin proteins was determined by the Pierce-BCA method.

Goldfish retinal explants. Goldfish retinal explants were prepared as previously described (Vielmetter and Stuermer, 1989). In brief, the optic nerves of adult goldfish were cut under MS-222 anesthesia. The retina was isolated 14-17 d later and attached to a nylon filter (Hybond, Amersham). Retina and filter werc cut into segments $300 \mu \mathrm{m}$ wide using a tissue chopper (Mcllwain) and explanted, ganglion cell layer down, onto coated coverslips. Small metal blocks were placed on the ends of the segments to keep the retina in contact with the substrate. The cultures were kept in L-15 (Leibovitz medium; GIBCO), supplemented with $10 \%$ fetal calf serum and $0.4 \%$ methyl cellulose at $23^{\circ} \mathrm{C}$. For miniex- plants, the isolated retillae were cut into small squares $(200 \times 200 \mu \mathrm{m})$ using a tissue chopper.

Outgrowth assays using goldfish retinal explants. Precleaned glass coverslips were incubated in a solution of $200 \mu \mathrm{g} / \mathrm{ml}$ polylysine (Sigma) in PBS for 1 hr at room temperature. After rinsing in distilled water and air-drying, suspensions of myelin $(100-500 \mu \mathrm{g} / \mathrm{ml})$ in PBS (containing protease inhibitors) were added $(200 \mu \mathrm{l}$ per $18 \times 18 \mathrm{~mm}$ coverslip) and spun down onto the coverslips for $20 \mathrm{~min}$ and $4000 \mathrm{rpm}$ at $4^{\circ} \mathrm{C}$. Unattached myelin particles were subsequently washed off with $\mathrm{L}-15$. Coverslips were then incubated for $2 \mathrm{hr}$ at room temperature with hybridoma supernatants containing Mabs O1, O4 (Sommer and Schachner, 1981), or IN-1. Controls were incubated with hybridoma medium (Iscove's MEM (GIBCO) with 5\% FCS) without antibodies. The hybridoma supernatants were removed before retinal explants were added.

Consecutive segments from the same retina were explanted on the various myelin substrates and incubated in $\mathrm{L}-15$ at $23^{\circ} \mathrm{C}$. Axonal outgrowth was monitored in an inverted microscope (Zeiss Axiovert) and the living axons were photographed after $48 \mathrm{hr}$.

For the first quantitative growth assay (described in Fig. 3) about 10 goldfish retinal miniexplants were placed on each coverslip carrying myelin in $500 \mu \mathrm{l} \mathrm{L-15}$. To keep the explants in place, an uncoated coverslip was put on top supported by two stainless steel spacers, thus forming a "sandwich" with the culture medium suspended between the two coverslips. Cultures were grown for $48 \mathrm{hr}$ at $23^{\circ} \mathrm{C}$ and axons per explant counted in the living cultures using phase contrast optics and an inverted microscope (Zeiss Axiovert).

For the second quantitative growth assay (described in Fig. 4) equal amounts of resuspended myelin $(5 \mu \mathrm{g} /$ well) were centrifuged onto the bottoms of 96-well dishes (Nunc). After rinsing in L-15 miniexplants (one per well) were added. Cultures were grown for $48 \mathrm{hr}$ at $23^{\circ} \mathrm{C}$ in $100 \mu \mathrm{l}$ of L-15 and then fixed in $5 \%$ glutaraldehyde in $0.1 \mathrm{M}$ phosphate buffer. The numbers of axons emerging from each explant were counted using phase-contrast optics (Zeiss Axiovert), as described earlier (Vielmetter and Stuermer, 1989; Bastmeyer et al., 1991; Lang et al., 1995).

Outgrowth assay with rat DRG neurons. DRG neurons were prepared from postnatal day $2-4$ rat pups. They were dissected in L-15, freed of connective tissue and nerve roots, and cut into small pieces on a McIlwain tissue chopper. The fragments were resuspended in L-15 containing $10 \%$ FCS and passed repeatedly through a Pasteur pipette with a rounded tip to mechanically dissociate the tissue. Remaining tissue aggregates were allowed to settle for $10 \mathrm{~min}$, the suspended cells were centrifuged briefly and resuspended in enriched L- 15 culture medium containing $5 \%$ FCS and $100 \mathrm{ng} / \mathrm{ml}$ nerve growth factor (NGF, Sigma). DRG neurons were plated onto coverslips at low density (approximately $200 \mathrm{cells} / \mathrm{cm}^{2}$ ) and grown at $37^{\circ} \mathrm{C}$. In these assays, myelin/polylysinecoated coverslips were preincubated $\left(15 \mathrm{~min}\right.$ at $\left.37^{\circ} \mathrm{C}\right)$ with the hybridoma supernatants containing Mabs $\mathrm{O} 1, \mathrm{O} 4$, or IN-1, or with hybridoma medium only (Iscove's MEM with 5\% FCS) for controls. The hybridoma supernatants were also present in the culture medium ( $1: 3$ dilution) throughout the culture period. After $24 \mathrm{hr}$, cultures were fixed with methanol $\left(-20^{\circ} \mathrm{C}, 5 \mathrm{~min}\right)$ and $4 \%$ paraformaldehyde in PBS at room temperature (RT). After three washes in PBS ( 5 min each) they were incubated in a rabbit antiserum against $L 1$ (kindly provided by $F$. Rathjen) at a 1:500 dilution over $2 \mathrm{hr}$ at RT. Cultures were washed in PBS $(3 \times 5 \mathrm{~min})$ and incubated for $2 \mathrm{hr}$ in Cy3-conjugated donkey antirabbit secondary antibody (1:1000 in PBS, Jackson ImmunoResearch). After a brief wash in PBS, cultures were mounted in Mowiol. Labeled cells were recorded on videotape using a SIT camera. For measurements of neurite length, only cells with distinct processes longer than $80 \mu \mathrm{m}$ were included. Quantification of adherent cells was achieved by counting all L1-labeled cells on each coverslip.

Collapse assay. Myelin from bovine spinal cord and goldfish optic nerves was prepared as described above and osmotically shocked with ice-cold water. Myelin preparations were subsequently extracted with ice-cold $60 \mathrm{~mm}$ CHAPS, $20 \mathrm{~mm}$ TRIS (pH 8), $100 \mathrm{mM} \mathrm{Na}_{2} \mathrm{SO}_{4}$ in the presence of $1 \mathrm{~mm}$ PMSF, $1 \mathrm{~mm}$ EDTA, $2.5 \mathrm{~mm}$ iodoacetamide, $2 \mu \mathrm{g} /$ $\mathrm{ml}$ aprotinin. $1 \mu \mathrm{g} / \mathrm{ml}$ pepstatin, and $1 \mu \mathrm{g} / \mathrm{ml}$ leupeptin. This extraction procedure results in a fivefold enrichment of myelin specific proteins as determined by Western blots using a Mab against myelin basic protein; $200-500 \mu \mathrm{g}$ of extracted myelin proteins were combined with a 10-fold excess of egg lecitin (grade 1, Lipid products). The mixture was put on ice for $1 \mathrm{hr}$ before liposomes were allowed to form by dialysis against PBS for $48 \mathrm{hr}$ at $4^{\circ} \mathrm{C}$. Buffer was changed three to four times and the last step was dialysis against the appropriate culture medium (L-15). Protein incorporation was approximately $60 \%$ and reflects ap- 
proximately $2 \mu \mathrm{g}$ protein $/ 10 \mu \mathrm{l}$ of liposomes. These liposomes were either used directly in the collapse assay or incubated with hybridoma supernatant containing IN-1 $(1: 3, v: v)$ at $4^{\circ} \mathrm{C}$ overnight before addition to the cultures.

Segments of goldfish retinae were cultured in $400 \mu$ l modified L-15 with FCS but without methylcellulose at $27^{\circ} \mathrm{C}$ on polylysine/laminincoated coverslips. The cultures were observed at room temperature with an inverted microscope and phase contrast optics. The growing axons were recorded using a video camera (Newvicon, Hamamatsu) and an image processing system (Hamamatsu DVS 3000). Images were taken every $5 \mathrm{sec}$ controlled by a magnetic shutter combined with an electronic device and were recorded on a time-lapse video recorder (S-VHS, Panasonic). Images were obtained from a video graphic printer (UP$860 \mathrm{CE}$, Sony). Alternatively, retinal cultures were observed with differential interference contrast optics. Images were taken at variable intervals and processed using the software IMAGE 1.

Liposomes were applied to the cultures with a microliter syringe (Hamilton) directly into the medium. The cultures were recorded for 10-15 min before adding the liposomes. Only growth cones that were motile were included in the experiment.

DRG cultures were prepared as described above. For time-lapse videomicroscopy, the cultures were kept on a heatable stage at $37^{\circ} \mathrm{C}$.

\section{Results}

Growth-permissive properties of goldfish optic nerve-derived myelin

Using a special procedure on tissue sections (Rubin et al., 1994) growth inhibitors (NI) can be detected with the antibody IN-1 (Caroni and Schwab, 1988b). In goldfish optic nerves, a weak but notable staining was present on myelin and was coextensive with Mab 6D2-immunoreactivity (Fig. 1). Cranial and spinal nerves, both from the fish PNS, were stained by Mab 6D2, but were IN-1 negative. Whether IN-1 staining in the fish visual system is indicative of the presence of functional neurite growth inhibitors was assessed in several outgrowth assays.

Segments of goldfish retinae were explanted onto polylysinecoated coverslips carrying goldfish optic nerve myelin. Numerous and long retinal axons extended on goldfish myelin (Fig. $2 a$ ). Pretreatment of myelin with Mab IN-1 did not increase the number or length of axons growing on it (Fig. $2 b$ ). The density of axons on myelin (Fig. 2a,b) made it impossible to count them. Surprisingly, axon density was markedly reduced when myelin was pretreated with Mab O4 (Fig. $2 c$ ) which was used to serve as control antibody in other studies (Sivron and Schwarz, 1994; Sivron et al., 1994a). Why Mab O4 negatively affects goldfish retinal axon growth is unclear but this effect was reproducible (see below). These experiments were repeated three times with different retinae and yielded similar results.

To quantify axon growth, two quantitative outgrowth assays using miniexplants of defined size $(200 \times 200 \mu \mathrm{m})$ were performed. The axons per square of retina were counted and axon numbers of each experimental set were averaged. In the first assay, polylysine-treated coverslips were coated with myelin fragments. In two assays, the myelin was incubated with antibodies prior to the addition of retinal miniexplants. The average number of axons was $9.9( \pm 0.83 \mathrm{SE})$ on goldfish optic nerve myelin per se, and $9( \pm 0.93 \mathrm{SE})$ on goldfish optic nerve myelin treated with IN-1 (Fig. 3). However, as in the experiment using retinal segments (Fig. 2), O4 (and O1, not shown) caused a reduction of the average number of axons (3.8 $\pm 0.35 \mathrm{SE})$. Outgrowth on fish optic nerve myelin was compared to that on rat CNS myelin. Consistent with earlier results (Bastmeyer et al., 1991, Lang et al., 1995) the average number of axons on rat myelin was low $(1 \pm 0.26 \mathrm{SE})$. On polylysine alone $14.3( \pm 1.08$ SE) axons were counted.

In the second quantitative assay polylysine undercoating was
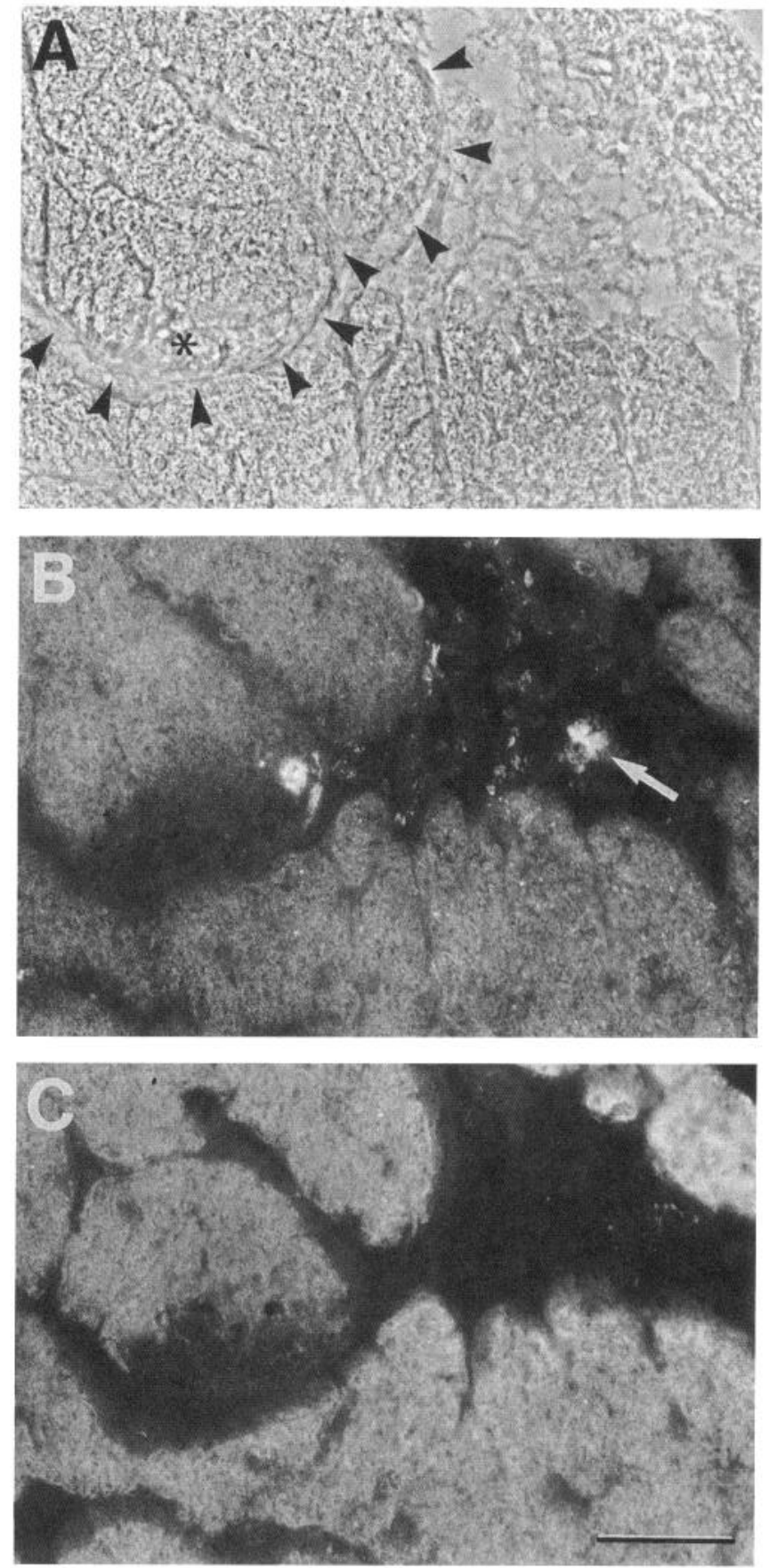

Figure 1. Cryosections through the goldfish optic nerve $(A$, phase contrast), treated according to Rubin et al. (1994) exhibited a weak staining with Mab IN-1. IN-1 staining $(B)$ was similar to that of the fish myelin marker Mab 6D2 $(C)$, applied to an adjacent section. $A r$ rowheads in $A$ demarcate a fascicle of the optic nerve, the asterisk marks the location of new and unmyelinated axons which are free of $6 \mathrm{D} 2$ and $\mathrm{IN}-1$ staining. The arrow in $B$ points to staining of artefacts. Scale bar, $50 \mu \mathrm{m}$.

omitted and myelin alone was applied to the bottom of wells of multiwell dishes. Moreover, Mabs IN-1 and $\mathrm{O} 4$ were added to the culture medium to exclude the possibility that antibody pretreatment of the myelin is insufficient to block neurite growth inhibitors. Again, equal numbers of axons were counted on untreated goldfish optic nerve myelin $(5.7 \pm 0.63 \mathrm{SE})$ and in the presence of IN-1 (5.9 $\pm 0.73 \mathrm{SE}$ ) (Fig. 4). As before (Figs. 2, 

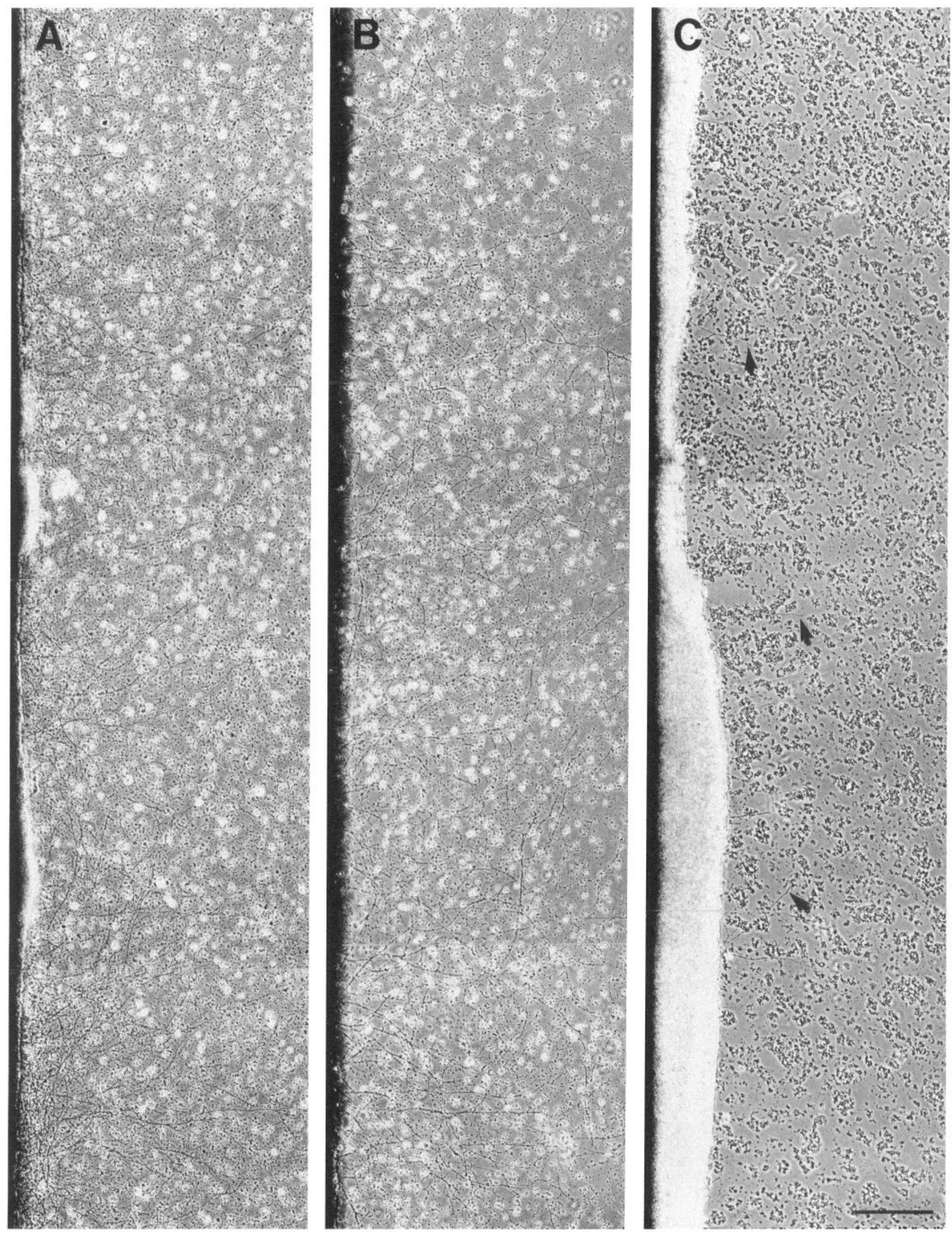

Figure 2. A, Goldfish retinal explants (to the left) extend an impressive number of axons on a substrate consisting of fish optic nerve myelin. $B$, When myelin fractions were treated with Mab IN-1, the density of axons was unchanged. $C$, Treatment of myelin with Mab O4 resulted in a marked reduction of axonal density. Also, the myelin fragments clumped when treated with O4. Arrows in $C$ point to axons. Scale bar, $200 \mu \mathrm{m}$. 


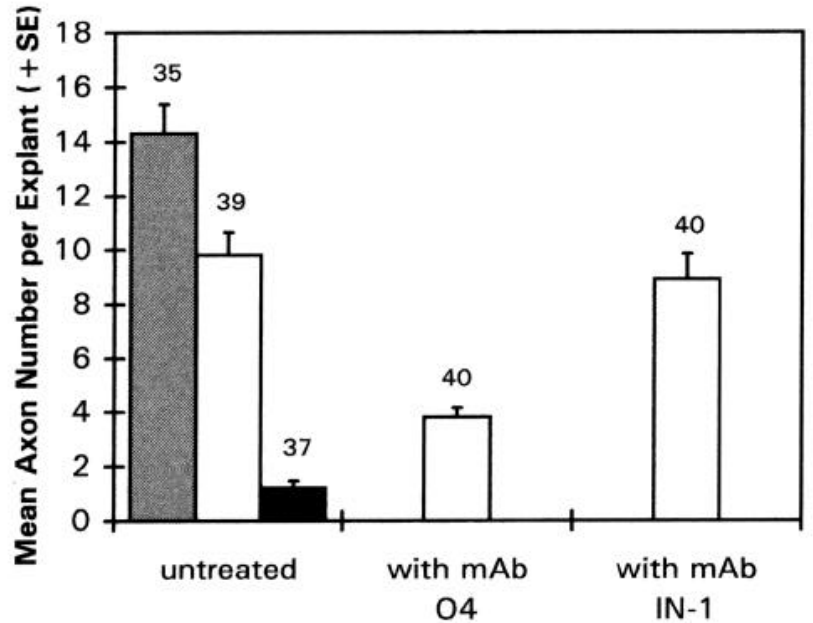

Substrate

Figure 3. Histogram demonstrating the number of axons, extending from goldfish retinal miniexplants on polylysine-coated coverslips with CNS myelin substrates after $48 \mathrm{hr}$. The average number of axons on fish optic nerve myelin was roughly 10 times that observed on rat CNS myelin, but was lower than on polylysine. A marked reduction in average number of axons was noted on Mab $\mathrm{O} 4$ preincubated fish myelin preparation but not in the case of preincubation with IN-1. Open bars, goldfish optic nerve myelin; solid bar, rat CNS myelin; shaded bar, polylysine. The heights of the bars represent the mean numbers of axon per explant with the SE indicated at the top of each bar. Number of explants above each bar.

3), $\mathrm{O} 4$ (and O1; not shown) caused a marked reduction of axon outgrowth $(1.9 \pm 0.25 \mathrm{SE})$. The number of goldfish retinal axons on rat CNS myelin was low $(1 \pm 0.25 \mathrm{SE})$ (Fig. 4), but was raised to $3.5( \pm 0.36 \mathrm{SE})$ when $\mathrm{IN}-1$ was present, indicating that the antibody is functionally active in this assay system.

Besides showing that $\mathrm{O} 4$ (and $\mathrm{O} 1$ ) are inappropriate as control antibodies using goldfish retinal axons and fish optic nerve myelin, these results indicate that the permissive substrate properties of goldfish optic nerve myelin are not improved by IN-1. However, Mab IN-1 causes a significant rise in number of axons when explants are exposed to rat CNS myelin. These data confirm that goldfish retinal axons are sensitive to the inhibitory substrate properties of rat CNS myelin. Their substantial growth on fish optic nerve myelin supports the notion that fish CNS myelin is growth permissive. These properties are unaltered by IN-1.

\section{Rat DRG neurite extension on goldfish optic nerve myelin}

The sensitivity of rat DRG neurons to rat neurite growth inhibitors was shown in earlier experiments (Bandtlow et al., 1990, 1993). Therefore, they were used in this study to test for the presence of neurite growth inhibitors in goldfish myelin. DRGs obtained from postnatal rats were seeded onto goldfish optic nerve myelin on polylysine-coated coverslips and on polylysine alone. After $36 \mathrm{hr}$ in culture, DRGs extended neurites with an average length of $324 \mu \mathrm{m}( \pm 25 \mathrm{SE})$ on polylysine alone (Fig. $5)$. On goldfish myelin, neurite length was $248 \mu \mathrm{m}( \pm 11 \mathrm{SE})$. Goldfish myelin with IN-1 as the substrate gave similar average lengths of neurites $(224 \mu \mathrm{m} \pm 11 \mathrm{SE})$ (Fig. 5). With rat DRGs, O4 (and O1, not shown) had no negative effect on neurite growth (264 $\mu \mathrm{m} \pm 12 \mathrm{SE})$ (Fig. 5) on fish myelin. These results demonstrate that goldfish optic nerve myelin represents a permissive substrate for DRG neurites. As demonstrated earlier, rat

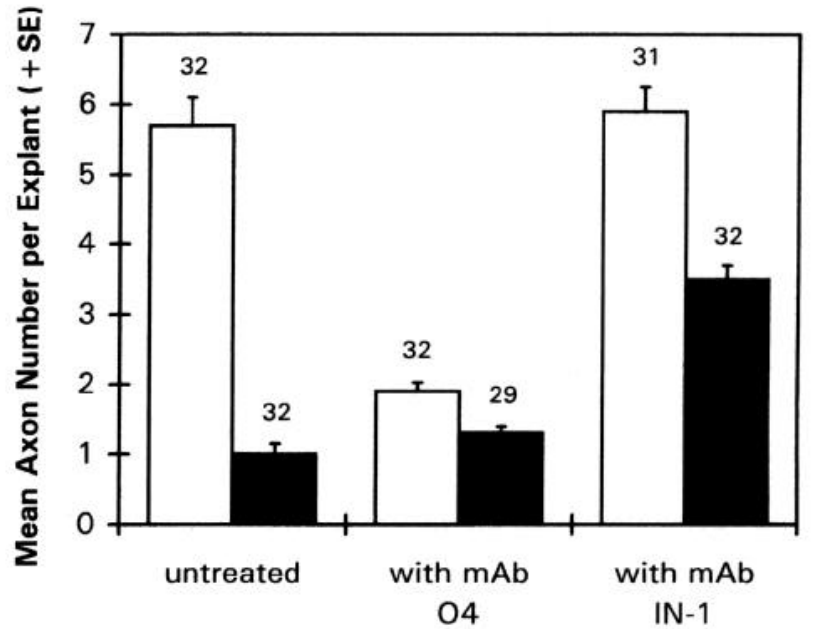

Substrate

Figure 4. Histogram showing the average number of goldfish retinal axons extending from miniexplants on CNS myelin substrates. The bottom of wells of 96 well dishes were covered with myelin fractions. The antibodies Mab O4 and IN-1 were present in the culture medium during the $48 \mathrm{hr}$ allowed for axon outgrowth. Mean number of axons is indicated by the heights of the bars with the SE shown at the top. Number of explants above each bar. Open bars, goldfish optic nerve myelin; solid bars, rat CNS myelin. The average number of goldfish retinal axons on goldfish optic nerve myelin is substantial. While unchanged in the presence of $\mathrm{IN}-1$, axon numbers decrease markedly with $\mathrm{O} 4$. The number of axons on rat CNS myelin is low, and remains low in the presence of $\mathrm{O} 4$, but increases significantly in the presence of $\mathrm{IN}-1$.

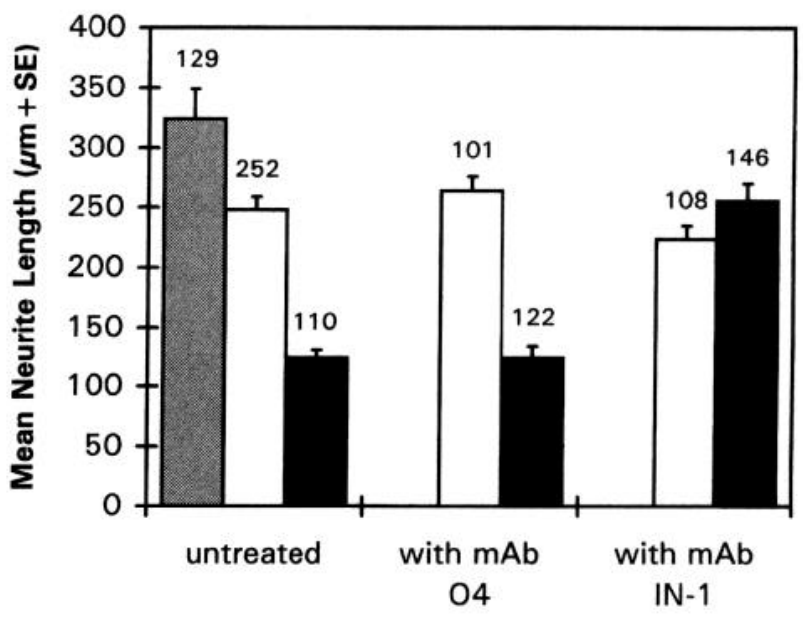

Substrate

Figure 5. Histogram illustrating the mean length of rat DRG neurites growing on CNS myelin substrates. The heights of the bars represent neurite length. SE is given at the top and number of neurites above each bar. Open bars, goldfish optic nerve myelin; solid bars, rat CNS myelin; shaded bar, polylysine. The average length of DRG neurites on goldfish optic nerve myelin is similar with no antibody (untreated) or with $\mathrm{O} 4$ or $\mathrm{IN}-1$ in the medium, and lower than on polylysine. On rat CNS myelin, average neurite length of DRGs is roughly $50 \%$ of that observed on fish optic nerve myelin, and unchanged with $\mathrm{O} 4$. With IN1 , however, average neurite length on rat CNS myelin resembles that seen on fish optic nerve myelin. 

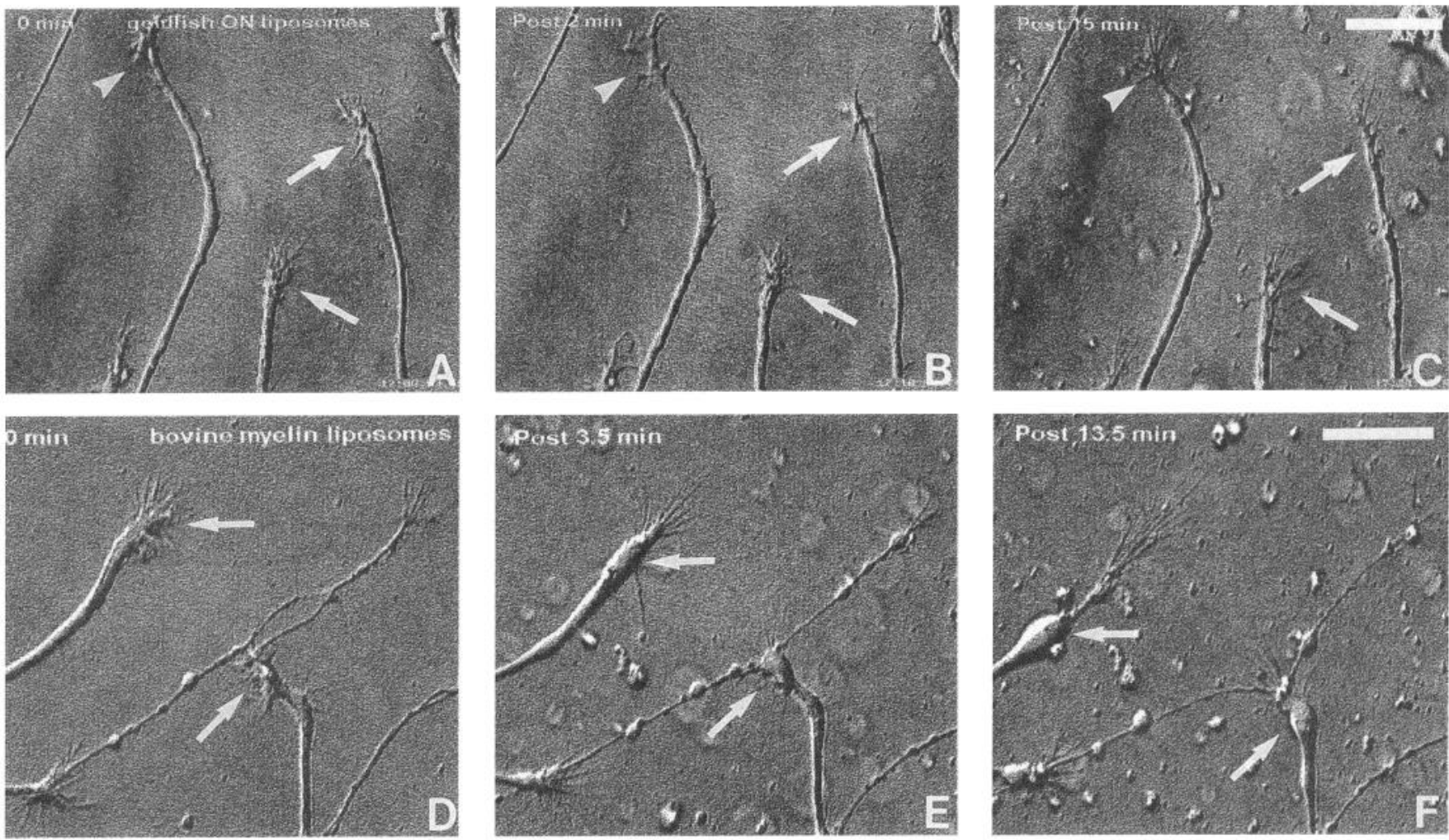

Figure 6. Selected images of sequences showing fish retinal growth cones: $A$, prior to the addition of liposomes; $B$, at the time that liposomes containing proteins of goldfish optic nerve myelin contact the growth cones; $C, 15 \mathrm{~min}$ after liposome addition. Growth cones (arrows and arrowhead, $A-C)$ exhibit subtle changes in their morphology after addition of the liposomes. Arrowhead $(A-C)$ shows a growth cone which is unaffected by the addition of the liposomes. The growth cone (arrow, to the right) retracts part of its lamellopodium $(B)$, whereas the other growth cone marked by an arrow retracts some of its filopodia $(B)$. All growth cones resume their normal shape and motility within 15 min $(C)$. $D-F$, Growth cones collapse and retract their axons when contacted by liposomes with bovine myelin proteins as is most evident by the two large growth cones (arrows). Note the retraction bulbs, typical features of collapsed and retracting growth cones $(F)$. Scale bar, $25 \mu \mathrm{m}$.

CNS myelin is a nonpermissive substrate for DRG neurons. Most DRGs failed to adhere when seeded on rat CNS myelin. Those which did extend neurites exhibited neurite length of 124 $\mu \mathrm{m}( \pm 7 \mathrm{SE})$. This average length was similar with Mab O4 treatment of CNS myelin. However, when rat CNS myelin was preincubated with IN-1, more DRG neurons adhered. The average neurite length was comparable to that observed on goldfish optic nerve myelin $(256 \mu \mathrm{m} \pm 14 \mathrm{SE})$.

\section{Effects of goldfish optic nerve-derived myelin proteins reconstituted in liposomes and seeded onto growing axons}

Myelin associated neurite growth inhibitors can be enriched by extracting myelin proteins with detergent. CHAPS-extracted proteins of both bovine CNS and goldfish optic nerves were reconstituted in liposomes (Caroni and Schwab, 1988b; Bandtlow et al., 1993) and applied to goldfish retinal or rat DRG growth cones elongating on a polylysine/laminin substrate. The behavior of individual growth cones was monitored before, during, and after application of the liposomes. Selected images of time-lapse movies (Fig. 6) illustrate goldfish retinal growth cones elongating in vitro prior to and during the addition of liposomes, which either contained goldfish or bovine myelin proteins.

When liposomes with CHAPS-extracted goldfish myelin proteins were applied, three types of growth cone responses were observed. The growth cones continued to migrate after application. Alternatively, the growth cones ceased to elongate, re- tracted some of their filopodia and lamellipodia, and remained in this state for up to $15 \mathrm{~min}$ before resuming their growth with newly formed lamellipodia and filopodia. These two reactions were categorized as no collapse (Fig. 7). The third type of reaction was bona fide growth cone collapse. Growth cones withdrew all of their lamellipodia and filopodia, often retracted their axon. They exhibited typical retraction bulbs and failed to resume growth during the $1 \mathrm{hr}$ observation period after addition of the liposomes (Fig. 6). Axon growth and growth cone morphologies were unchanged with control liposomes free of any protein. The frequency of these responses is documented in Figure 7.

Liposomes with goldfish optic nerve myelin proteins allowed goldfish retinal growth cones to continue their growth either immediately or after $10-15 \mathrm{~min}$ in $77 \%(n=43)$ of all observed cases. In $23 \%(n=13)$ of all instances, however, growth cones collapsed (Fig. 7).

When liposomes with goldfish optic nerve myelin proteins were incubated overnight with Mab IN-1 and then added, 80\% $(n=20)$ of fish growth cones continued their growth, again either immediately or after $10-15 \mathrm{~min} ; 20 \%(n=5)$ of growth cones collapsed (Fig. 7). The similarity of number of growth cones which collapsed or continued to grow in both these experiments suggests that IN-1 had no neutralizing effect with goldfish myelin proteins. This was confirmed by statistical tests that revealed no difference between the experiments $\left(\chi^{2}=0.1\right.$, $P>0.75)$. 


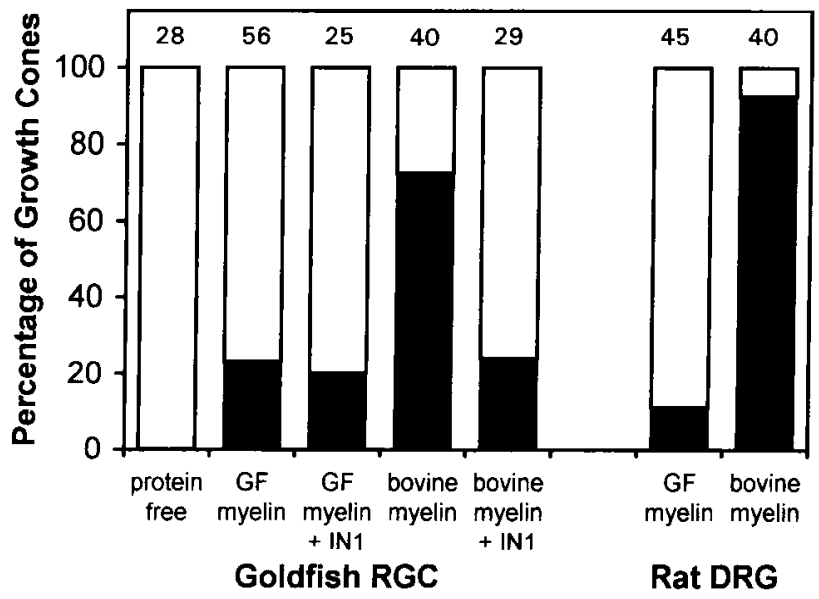

Figure 7. Quantification of growth cone responses when liposomes containing CNS myelin proteins were seeded onto goldfish $(G F)$ retinal ganglion cell $(R G C)$ growth cones or onto rat $D R G$ growth cones. Solid portions of the bars represent the percentage of collapsing growth cones. No goldfish growth cone collapsed with protein-free liposomes. With goldfish optic nerve myelin proteins incorporated in liposomes, $23 \%$ of GF growth cones collapsed and $20 \%$ with $\mathrm{IN}-1$ preincubated liposomes, but $73 \%$ collapsed with proteins of bovine CNS. Collapse responses were reduced to $24 \%$ with bovine CNS myelin proteins preincubated with IN-1; 93\% of rat DRG growth cones collapsed when liposomes with bovine CNS myelin proteins contacted them, but only $11 \%$ collapsed with liposomes loaded with goldfish optic nerve myelin proteins. Number of growth cones above each bar.

IN-1 did, however, neutralize collapse-inducing activities of bovine myelin proteins. Liposomes with proteins from bovine CNS myelin added to goldfish retinal growth cones elicited collapse within $5 \mathrm{~min}$ after application. $72.5 \%(n=29)$ of growth cones collapsed showing no growth recovery after $15 \mathrm{~min}$. $27.5 \%(n-11)$ of growth cones showed no morphological responses, but continued to grow after the addition of bovine myelin protein-loaded liposomes. Incubation of these liposomes in IN-1, however, prevented the collapse in $76 \%(n=22)$ of the observed growth cones and only $24 \%(n=7)$ responded with collapse after addition of IN-1 treated bovine proteins (Fig. 7). This reduction in growth cone collapse with IN-1 treated bovine myelin proteins as compared to bovine myelin proteins without IN-1 was statistically significant $\left(\chi^{2}=15.75, P<0.0001\right)$. These results confirm that goldfish retinal growth cones are sensitive to the same inhibitory proteins of mammalian CNS myelin as mammalian axons themselves. Their sensitivity to the bovine inhibitory activity may be lower (Bastmeyer et al., 1991) than the sensitivity of rat DRGs, as demonstrated below.

When using rat DRG neurons as recipients of the bovine myelin proteins incorporated in liposomes, 92.5\% $(n=37)$ of DRG growth cones collapsed. This also indicates that the inhibitory activity of the proteins in the liposomes of the present experiments was normal. DRG growth cones also received liposomes with goldfish myelin proteins. $89 \%(n=40)$ of DRG growth cones grew unaffectedly, and $11 \%(n=5)$ collapsed (Fig. 7). Again this difference in responses of DRG growth cones to bovine myelin protein and fish myelin protein was statistically significant $\left(\chi^{2}=23.03, P<0.0001\right)$. This indicates that goldfish myelin proteins do not possess significant amounts of inhibitory proteins because not only fish growth cones but even the more sensitive rat DRG growth cones continued to grow in the majority of instances.

\section{Discussion}

In this study the growth of goldfish retinal axons and rat DRG neurites was used to evaluate the substrate properties of goldfish optic nerve-derived myelin and myelin proteins and to determine whether Mab IN-1 neutralizes potential inhibitors associated with fish myelin.

Consistent with earlier results outgrowth of goldfish retinal axons was substantial on goldfish optic nerve myelin (Bastmeyer et al., 1991; Lang et al., 1995), as was that of rat DRG neurites. There was no increase in number of axons or DRG neurite length in the presence of IN-1, indicating the absence of IN-1 mediated neutralization of potential inhibitors. Moreover, fractions enriched in fish optic nerve myelin proteins and applied in liposomes to growth cones allowed fish growth cone elongation in the majority $(77 \%)$ of instances. Fish growth cones exhibiting collapse were $23 \%$. With protein-loaded liposomes preincubated with IN-1 collapse rate was $20 \%$. Thus, fish optic nerve myelin either lacks mammalian-like inhibitors neutralizable by $1 \mathrm{~N}-1$, or it contains trace amounts of this activity, which is not detectable by observing the growth of axons on myelin as a substrate.

Fish optic nerves contain considerable amounts of myelin debris after optic nerve transection when regenerating axons pass through the nerve and tract into the tectum (Strobel and Stuermer, 1994; Hirsch et al., 1995). The present findings together with those of earlier studies (Bastmeyer et al., 1991; Strobel and Stuermer, 1994) suggest that fish optic nerve myelin does not impair axonal regeneration. This is consistent with the success of axonal regeneration by retinal ganglion cell axons in this system.

Both types of axons in the present in vitro assays are sensitive to neurite growth inhibitors, and both exhibit improved growth after neutralization of these inhibitors by IN-1 (Bandtlow et al., 1990, 1993; Bastmeyer et al., 1991; Lang et al., 1995). This was confirmed in the present study using rat CNS myelin as a substrate for axonal growth and with a protein fraction derived from bovine CNS myelin (Bandtlow et al., 1993). The sensitivity to neurite growth inhibitors-repeatedly shown for rat DRGs (Schwab and Thoenen, 1985; Bandtlow et al., 1990, 1993)was also detected earlier for goldfish retinal axons (Bastmeyer et al., 1991; Lang et al., 1995). That fish axons respond to the same inhibitor proteins as mammalian axons was concluded from experiments with IN-1. While collapse of growth cones or avoidance of inhibitor-bearing oligodendrocytes was a typical response of fish axons to oligodendrocytes of rats (Bastmeyer et al., 1991) and Xenopus spinal cord (Lang et al., 1995), these axons were able to cross these glial cells upon neutralization of the inhibitory activity by IN-1. Since both DRG neurites and goldfish retinal axons grow well on fish optic nerve-derived myelin, we conclude that typical inhibitors known from mammals are either not present in goldfish optic nerves or are expressed in minor quantities which remain undetectable by the present assays. This conclusion is supported by the outcome of the collapse assays (Bandtlow et al., 1993). While liposomes with bovine myelin proteins caused collapse of the majority of DRG and goldfish growth cones, the majority of growth cones continued to elongate when liposomes with goldfish optic nerve myelin protein were seeded on them. Morcover, most of the collapse-inducing activity was neutralized by $\mathrm{IN}-1$ in the case of liposomes with bovine proteins. Roughly $76 \%$ of goldfish growth cones then continued to grow whereas a similar number (73\%) collapsed without IN-1. 
With fish myelin proteins and $\mathrm{IN}-1$ the fraction of elongating growth cones was very similar to that found without IN-1. It seems reasonable to conclude that there are no or at best only traces of mammalian-like neurite growth inhibitors among the goldfish optic nerve-derived myelin proteins. This supports the outcome of the outgrowth assays with myelin as substrates for fish and DRG neurites.

The observation that up to $24 \%$ of fish growth cones do collapse when contacted by liposomes with fish myelin proteins speaks, however, for the presence of some collapse-inducing proteins which differ from the known mammalian neurite growth inhibitors in that their activity is unaffected by IN-1. Moreover, it appears that fish axons are more sensitive to such proteins than rat DRGs because collapse of fish growth cones $(23 \%)$ is twice that of DRG growth cones (11\%). Either a fish specific inhibitor exists which is not recognized by IN-1 or fish optic nerve myelin contains other proteins capable of inducing collapse when enriched by the method applied here.

An unexpected finding was the reduction of fish retinal axon growth (but not rat DRG growth) when fish myelin was pretreated with $\mathrm{O} 4$ and $\mathrm{Ol}$ antibodies or when these antibodies were present in the medium. One possible explanation for this phenomenon is that these antibodies may cover myelin molecules in fish which promote fish axon growth because no reduction of axon growth was noted with $\mathrm{O} 4$ and $\mathrm{Ol}$ when axons elongated on polylysine. In our hands neither $\mathrm{O} 4$ nor $\mathrm{Ol}$ are suited for control experiments in the present or related assays with fish myelin (but see Sivron et al., 1994; Sivron and Schwartz, 1994a).

Although fish, Xenopus, and rat neurons are able to grow on fish optic nerve myelin, myelin is not a particularly good substrate for axon growth. Even polylysine, which in its growthpromoting effects is far below laminin or other proteins, allows formation of longer neurites in the case of rat DRGs and outgrowth of more fish axons than fish myclin (here and Bastmeyer et al., 1991). Likewise, rat CNS myelin or rat oligodendrocytes treated with $\mathrm{IN}-1$ do not become particularly favorable substrates for neurite growth. Thus, neurite growth inhibitors may not be the only cause for the unfavorable substrate properties of CNS myelin in vivo. However, there is a correlation between presence of CNS inhibitors and lack of axonal regeneration (mammals: reviewed in Schwab et al., 1993; chick: Keirstead et al., 1992; amphibians: Lang et al., 1995) and between the absence or low level expression of inhibitors and successful axonal regrowth (fish: Bastmeyer et al., 1991; amphibians: Lang et al., 1995; chick: Keirstead et al., 1992; rat: Schnell and Schwab, 1990; Weibel et al., 1994; Aguayo et al., 1991) in vertebrates analyzed to date.

That successful axonal regeneration is not solely dependent on the absence of inhibitors from myelin has been discussed rcpeatedly (for instance Reier et al., 1983; Schnell and Schwab, 1993; Strobel and Stuermer, 1994). In the fish optic nerve as well as in peripheral nerves of mammals, growth-supportive molecules are expressed while axons regenerate (fish: Battisti et al., 1992; Hopkins et al., 1985; Hirsch et al., 1995; Stuermer et al., 1992; mammalian PNS, reviewed in: De Vellis, 1993).

Proteins present in CNS myelin and known to cause poor growth or avoidance behavior of growing axons under particular conditions are tenascin, janusin (Pesheva et al., 1989; Taylor et al., 1993) and MAG (Mukhopadhyay et al., 1994; McKerracher et al., 1994). However, at least in the case of rat neurons they do not elicit growth cone collapse (janusin: Taylor et al., 1993; tenascin and MAG: C. Bandtlow and M.E. Schwab, unpublished results). Thus, it is unlikely that tenascin and MAG, which were detected by immunostaining in fish optic nerves (M. Bastmeyer and D. Lang, unpublished results) are responsible for the $23 \%$ collapse response. The $23 \%$ collapse responses seen with fish myelin proteins, and the $24 \%$ with bovine myelin proteins after neutralization of the known neurite growth inhibitors by IN-1 rather suggest that additional inhibitors such as chondroitin-sulfate-proteoglycans (Snow et al., 1993) or other yet uncharacterized proteins (McKerracher et al., 1994) are present.

In rats and Xenopus, staining of tissue sections with IN-1 correlates with myelinated CNS fiber tracts and inhibitory substrate properties of myelin and oligodendrocytes from these regions (Rubin et al., 1994; Lang et al., 1995). IN-1 staining is absent from PNS myelin, in these species as well as in fish. In sections of the fish CNS, however, IN-1 staining in the spinal cord and in tectal efferent axons was directly associated with axons, and closely resembled that with Mab M501 against goldfish neurofilament proteins (Paschke ct al., 1992) and therefore was unspecific in these regions. In the fish optic nerve and tract, IN-1 staining was weak but coextensive with labeling of the myelin marker Mab 6D2 (Jeserich and Waehneldt, 1986; Bastmeyer et al., 1994). Whether this indicates the presence of low amounts of mammalian-like inhibitors, or another unspecific effect is not clear at present. Unfortunately, IN-1 does not recognize the two inhibitory proteins of 35 and $250 \mathrm{kDa}$ on immunoblots, either in mammals or in amphibian and fish material. However, in SDS gels with proteins of fish optic nerves, proteins of the relevant molecular weights, clearly detectable in mammalian CNS myelin, were not seen in fish (C. Bandtlow, unpublished results).

Whether oligodendrocytes of the fish visual system possess the relevant gene(s) and express mammalian-like inhibitors can be determined conclusively only once the cDNA is cloned. This will also clarify the pertinent question of when these proteins arose during evolution and when and where they are expressed during nervous system development.

\section{References}

Aguayo AJ, Rasminsky M, Bray GM, Carbonetto S, McKerracher L, Villegas-Pérez. MP, Vidal-Sanz M, Carter DA (199l) Degenerative and regenerative responses of injured neurons in the central nervous system of adult mammals. Philos Trans R Soc Lond [Biol] 331:337343.

Baehr M, Bonhoeffer F (1994) Perspectives on axonal regeneration in the mammalian CNS. Trends Neurosci 17:473-479.

Bandtlow C, Zachleder T, Schwab MF. (1990) Oligodendrocytes arrest neurite growth by contact inhibition. J Neurosci 10:3837-3848.

Bandtlow CE, Schmidt MF, Hassinger TD, Schwab ME, Kater SB (1993) Role of intracellular calcium in NI-35-evoked collapse of neuronal growth cones. Science 259:80-83.

Bastmeyer M, Beckmann M, Schwab ME, Stuermer CAO (1991) Growth of regenerating goldfish axons is inhibited by rat oligodendrocytes and CNS myelin but not by goldfish optic nerve/tract oligodendrocyte-like cells and fish CNS myelin. J Neurosci 1 1:626-640.

Bastmeyer M, Jeserich G, Stuermer CAO (1994) Similarities and differences between fish oligodendrocytes and Schwann cells. Glia 11: 300-314.

Battisti WP, Shinar Y, Schwartz M, Levitt P, Murray MM (1992) Temporal and spatial patterns of expression of laminin, chondroitin sulphate proteoglycan and $\mathrm{HNK}-1$ immunoreactivity during regeneration in the goldfish optic nerve. J Neurocytol 21:557-573.

Carbonetto S, Evans D, Cochard P (1987) Nerve fiber growth in culture on tissue substrates from central and peripheral nervous systems. J Neurosci 7:610-620.

Caroni P, Schwab ME (1988a) Two membrane protein fractions from 
rat central myelin with inhibitory properties of neurite growth and fibroblast spreading. J Cell Biol 106:1281-1288.

Caroni P, Schwab ME (1988b) Antibody against myelin-associated inhibitor of neurite growth neutralizes nonpermissive substrate properties of CNS white matter. Neuron 1:85-96.

Colman DR, Kreibich G, Frey AR, Sabatini DD (1982) Synthesis and incorporation of myelin polypeptides into CNS myelin. J Cell Biol 95:598-608.

De Vellis J (1993) Supporting cells, central and peripheral. In: Neuroregeneration (Gorio A, ed), pp 61-75. New York: Raven.

Fawcett JW (1992) Intrinsic neuronal determinants of regeneration. Trends Neurosci 15:5-8.

Gaze RM (ed) (1970) The formation of nerve connections. London: Academic.

Grafstein B., McQuarry JG (1978) Role of nerve cell body in axonal regeneration. In: Neuronal plasticity (Cotman C, ed), pp 155-195. New York: Raven.

Hirsch S, Cahill MA, Stuermer CAO (1995) Fibroblasts at the transection site of the injured goldfish optic nerve and their potential role during retinal axonal regeneration. J Comp Neurol, in press.

Hopkins JM, Ford-Holevinski TS, McCoy JP, Agranoff BW (1985) Laminin and optic nerve regeneration in the goldfish. $J$ Neurosci 5:3030-3038.

Jeserich G. Waehneldt TV (1986) Characterization of antibodies against major fish CNS myelin proteins: immunoblot analysis and immunohistochentical localization of $36 \mathrm{~K}$ and IP2 proteins in trout nervous tissue. J Neurosci Res 15:147-158.

Keirstead HS, Hasan SJ, Meir GD, Steeves JD (1992) Suppression of the onset of myelination extends the permissive period for the functional repair of embryonic spinal cord. Proc Natl Acad Sci USA 89: $11664-11668$.

Lang D, Rubin BP, Schwab ME, Stuermer CAO (1995) CNS myelin and oligodendrocytes of the Xenopus spinal cord-but not optic nerve-are nonpermissive for axon growth. J Neurosci 15:99-109.

McKerracher L, David S, Jackson DL, Koltis U, Dunn RJ, Braun PE (1994) Identification of myelin-associated glycoprotein as a major myelin-derived inhibitor of neurite growth. Neuron 13:805-811.

Mukhopadhyay G, Doherty P, Walsh FS, Crocker PR, Filbin MT (1994) A novel role for myelin-associated glycoprotein as an inhibitor of axonal regeneration. Neuron 13:757-767.

Paschke K, Lottspeich F, Stuermer CAO (1992) Neurolin, a cell surface glycoprotein on growing retinal axons in the goldfish visual system is re-expressed during retinal axonal regeneration. J Cell Biol 117 : 863-875.

Perry GW, Burmeister DW, Grafstein B (1987) Fast axonally transported proteins in regenerating goldfish optic axons. $J$ Neurosci 7:792-806

Pesheva P, Spiess E, Schachner M (1989) J1-160 and J1-180 are oligodendrocyte-secreted non-permissive substrates for cell adhesion. J Cell Biol 109:1765-1778.

Reier PJ, Stensaas LJ, Guth L (1983) The astrocytic scar as an impediment to regeneration in the central nervous system. In: Spinal cord reconstruction (Kao CC, Bunge RP, Reier PJ, eds), pp 163-193. New York: Raven.
Rubin B, Dusart J, Schwab ME (1994) A monoclonal antibody (IN-1) which neutralizes growth inhibitory proteins in the rat CNS recognizes antigens localized in CNS myelin. J Neurocytol 23:209-217.

Schnell L, Schwab ME (1990) Axonal regeneration in the rat spinal cord produced by an antibody against myelin-associated neurite growth inhibitors. Nature $343: 269-272$.

Schnell L, Schwab ME (1993) Sprouting and regeneration of lesioned corticospinal tract fibres in the adult rat spinal cord. Eur $\mathbf{J}$ Neurosci 5:1156-1171.

Schnell L, Schneider R, Kolbeck R, Barde Y-A, Schwab ME (1994) Neurotrophin-3 enhances sprouting of corticospinal tract during development and after adult spinal cord lesion. Nature 367:170-173.

Schwab ME, Thoenen H (1985) Dissociated neurons regenerate into sciatic but not optic nerve explants in culture irrespective of neurotrophic factors. J Neurosci 5:2415-2423.

Schwab ME, Kapfhammer J, Bandtlow CE (1993) Inhibitors of neurite growth. Annu Rev Neurosci 16:565-595.

Sivron T, Schwartz M (1994a) Nonpermissive nature of fish optic nerves to axonal growth is due to presence of myelin-associated growth inhibitors. Exp Neurol 130:411-413.

Sivron T, Schwartz M (1994b) The enigma of myelin-associated growth inhibitors in spontaneously regenerating nervous systems. Trends Neurosci 7:277-281.

Sivron T, Cohen A, Hirschberg DL, Jeserich G, Schwartz M (1991) Soluble factor(s) produced in injured fish optic nerve regulate the postinjury number of oligodendrocytes: possible role of macrophages. Glia 4:591-601.

Sivron T, Schwab ME, Schwartz M (1994) Presence of growth inhibitors in fish optic nerve myelin: postinjury changes. $J$ Comp Neurol 343:237-246.

Snow DM, Atkinson P, Hassinger T, Kater SB, Letourneau, PC (1993) Growth cone intracellular calcium levels are elevated upon contact with sulfated proteoglycans. Soc Neurosci Abstr 19:876.

Sommer J, Schachner M (1981) Monoclonal antibodies (OI to O4) to oligodendrocyte cell surfaces; an immunocytological study in the central nervous system. Dev Biol 83:311-327.

Strobel G, Stuermer CAO (1994) Growth cones of regenerating retinal axons contact a variety of cellular profiles in the transected goldfish optic nerve. J Comp Neurol, in press.

Stuermer CAO, Bastmeyer M, Bähr M, Strobel G, Paschke K (1992) Trying to understand axonal regeneration in the CNS of fish. J Neurobiol 23:537-550.

Taylor J, Pesheva P, Schachner M (1993) Influence of janusin and tenascin on growth cone behavior in vitro. J Neurosci Res 35:347362.

Vanselow J, Schwab ME, Thanos S (1990) Responses of regenerating rat retinal ganglion cell axons to contacts with central nervous myelin in vitro. Eur J Neurosci 2:121-125.

Vielmetter J, Stuermer CAO (1989) Goldfish retinal axons respond to position-specific properties of tectal cell membranes in vitro. Neuron 2:1331-1339.

Weibel D, Cadelli D, Schwab ME (1994) Regeneration of lesioned rat optic nerve fibers is improved after neutralization of myelin-associated neurite growth inhibitors. Brain Res 642:259-266. 